\title{
New hepatitis $C$ virus infection, re-infection and associated risk behaviour in male Irish prisoners: a cohort study, 2019
}

Des Crowley ${ }^{1,2^{*}}$, Gordana Avramovic ${ }^{1}$, Walter Cullen ${ }^{1}$, Collette Farrell ${ }^{2}$, Anne Halpin², Mary Keevans², Eamon Laird ${ }^{3}$, Tina McHugh ${ }^{4}$, Susan McKiernan ${ }^{5}$, Sarah Jayne Miggin ${ }^{6}$, Ross Murtagh ${ }^{1}$, Eileen O. Connor ${ }^{6}$, Marie O'Meara ${ }^{7}$, Deirdre O. Reilly ${ }^{2}$ and John S. Lambert ${ }^{1,4}$

\begin{abstract}
Background: Prisoners are recognised as a high-risk population and prisons as high-risk locations for the transmission of hepatitis c virus (HCV) infection. Injecting drug use (IDU) is the main driver of HCV infection in prisoners and harm reduction services are often suboptimal in prison settings. HCV prevalence and incident data in prisoners is incomplete which impacts the public health opportunity that incarceration provides in identifying, treating and preventing HCV infection. The aim of this study is to identify new HCV infection and associated risk factors in an Irish male prison.

Methods: We conducted a follow up (18-month) cohort study on prisoners who had previously tested negative, selfcleared or had been successfully treated for HCV infection. We conducted the study in a male medium security prison located in Dublin Ireland (Mountjoy Prison) using HCV serology, a review of medical records and a researcheradministered questionnaire.

Results: 99 prisoners with a mean age of $33.2 \mathrm{yrs}$. participated in the study and 82(82.8\%) completed a researchadministered questionnaire. Over half (51\%) had a history of drug use from a young age (14.8 yrs.), $49.9 \%$ a history of heroin use and 39\% a history of IDU. The prevalence of HIV and hepatitis B virus core antibody was 3\% and HCV antibody was 22.2\%. No new HCV infections were identified in those who had never been infected $(n=77)$, had selfcleared $(n=9)$ or achieved sustained virological response $(n=12)$. Small numbers of prisoners continued to engage in risk-behaviour including, IDU both in the prison $(n=2)$ and the community $(n=3)$, sharing syringes $(n=1)$ and drug taking paraphernalia $(n=6)$ and receiving non-sterile tattoos $(n=3)$.

Conclusion: Despite the high numbers of Irish prisoners with a history of IDU and HCV infection, new HCV infection is low or non-existent in this population. Small numbers of prisoners continue to engage in risk behaviour and larger studies are required to further understand HCV transmission in this cohort in an Irish and international context.
\end{abstract}

Keywords: Hepatitis C, HCV, Prisoner, Prison, Incident, Harm reduction, Medication assisted treatment, MAT

\footnotetext{
* Correspondence: doctordes@hotmail.com

'School of Medicine, University College Dublin, Dublin, Ireland

2Irish Prison Service, Dublin, Ireland

Full list of author information is available at the end of the article
}

\section{$\triangle B M C$}

(c) The Author(s). 2021 Open Access This article is licensed under a Creative Commons Attribution 4.0 International License, which permits use, sharing, adaptation, distribution and reproduction in any medium or format, as long as you give appropriate credit to the original author(s) and the source, provide a link to the Creative Commons licence, and indicate if changes were made. The images or other third party material in this article are included in the article's Creative Commons licence, unless indicated otherwise in a credit line to the material. If material is not included in the article's Creative Commons licence and your intended use is not permitted by statutory regulation or exceeds the permitted use, you will need to obtain permission directly from the copyright holder. To view a copy of this licence, visit http://creativecommons.org/licenses/by/4.0/ The Creative Commons Public Domain Dedication waiver (http://creativecommons.org/publicdomain/zero/1.0/) applies to the data made available in this article, unless otherwise stated in a credit line to the data. 


\section{Background}

Hepatitis C (HCV) infection is a major public health concern and a leading cause of liver-related morbidity and mortality worldwide [1]. Injecting drug use (IDU) is the major driver of $\mathrm{HCV}$ infection in developed countries $[1,2]$. Ongoing criminalisation of people who inject drugs (PWID) ensures an over representation of PWID and $\mathrm{HCV}$ infection in prison populations [3].

Epidemiological data on $\mathrm{HCV}$ infection in prisoners is lacking in many countries [3]. From available data it is estimated that over a quarter of prisoners globally have been infected with HCV increasing to over $60 \%$ in prisoners with a history of IDU [3]. Incident infection is estimated at 1.4 per 100 person-year (py) increasing to 16.6 per 100 py in prisoners with a history of IDU [3].

Ireland has one of the lowest incarceration rates in Europe with approximately 4000 people incarcerated across 14 locations in the Irish Prison Service (IPS) daily [4]. There are well-established medication assisted treatment (MAT) services across the entire prison estate but needle and syringe programmes (NSPs) are not available at any Irish prison location [5].

Studies on Irish prisoners report high rates of opioid use (50\%), IDU (43\%) and HCV infection (13-37\%) [68]. Recent national HCV screening guidelines recommend the screening of all prisoners and re-screening annually with targeted screening if a HCV transmission risk is identified [9]. However, these national guidelines have yet to be fully implemented. HCV treatment in Irish prisons is provided by specialist services. Ireland, like other developed countries, has a large proportion of undiagnosed and untreated $\mathrm{HCV}$-infected individuals incarcerated in its prisons [10].

The study site is one of three locations where in-reach hepatology services, through specialist nurses, are provided in the IPS. HCV direct-acting antivirals (DAAs) have been available in Ireland since 2014, with initial availability restricted on clinical need. DAAs (including 8 -week and pan-genotypic regimens) can now be prescribed to all $\mathrm{HCV}$-infected people needing treatment including prisoners.

This study is a follow up study from a previously published 2017 cross sectional study that estimated the prevalence of untreated chronic HCV infection and associated risk factors in a male Irish prisoners [11].

The 2017 study $(n=422)$ reported a HIV and hepatitis $B$ virus (HBV) core antibody prevalence of 4.0 and $3.0 \%$ respectively and a HCV antibody prevalence of $22.8 \%$ among the general prison population, increasing to $79.7 \%$ among prisoners with history of IDU [11]. Of the HCV antibody positive prisoners, $11 \%$ were co-infected with HIV. It also reported a chronic untreated $\mathrm{HCV}$ prevalence of $13.1 \%$ [11]. Of those with chronic infection; $58.7 \%$ were infected with Genotype 1A and 41.3\% with Genotype 3.
Similar to other national and international studies identified risk factors for HCV infection included: IDU, having received a prison tattoo and sharing syringes and drug taking paraphernalia [11-14].

A recent peer-led active case finding initiative at the study site found high levels of undiagnosed HCV infection and related liver disease (over 25\% of those fibroscanned showed evidence of liver disease) [10]. Peersupported screening identified 50 cases $(12 \%$ of the study population) of active untreated $\mathrm{HCV}$ infection of which 19 (5\% of the study population) had not been identified at committal. Of those identified $86 \%$ were linked with $\mathrm{HCV}$ care, with $33 \%$ undergoing or completing treatment.

Similar to other jurisdiction, Ireland struggles to increase rates of $\mathrm{HCV}$ screening and treatment in prisoners [12, 15, 16]. Barriers identified include: lack of knowledge, historical requirement to have a liver biopsy, the requirement to go to hospital, concerns regarding confidentiality, stigma experienced and inconsistent and delayed access to prison health services $[17,18]$.

Enablers identified include; access to health care, optout screening at committal, peer support, stability of prison life and in-reach hepatology services and fibroscanning [17].

The aims of this study are to estimate the HCV incident infection among Irish male prisoners and to describe levels of risk behaviour among prisoner who are aware of not having $\mathrm{HCV}$ infection or having a documented sustained virological response (SVR) posttreatment. This study will add to the existing literature on the epidemiology of $\mathrm{HCV}$ infection in prisoners including incident infection and risks. Findings will also evaluate the effectiveness of harm reduction services in Irish prisons and may inform future development of these services internationally.

\section{Methods}

This study reports on the final part of a larger European HCV seek and treatment study (HepCare Europe project) and was a follow up to a previously reported prevalence study completed in 2017 [11, 19]. Ethical approval for the research was granted by The Mater Misericordiae University Hospital Research Ethics Committee (Ref:1/ 378/1839) and the Irish Prison Service (IPS) Ethics Review Committee.

\section{Study design}

The original study included 422 participants of which 403 had HCV serology completed. This study found that 311 prisoners were $\mathrm{HCV}$ antibody negative and 92 (22.8\%) were HCV antibody positive. A review of medical records found of those who were $\mathrm{HCV}$ antibody positive $23(25 \%)$ had spontaneously cleared, $12(13 \%)$ 
had a sustained virological response (SVR) and 53 (57\%) had chronic infection.

A review of prison and medical records found that 99 of the original study participants who were either; $\mathrm{HCV}$ antibody negative $(n=77)$, had achieved spontaneous clearance $(n=9)$ or had an SVR post-treatment $(n=13)$ were incarcerated at the time of this updated study. All 99 prisoners agreed to participate in this follow up cohort study and 82 agreed to complete a researchadministered questionnaire which answers are presented in Table 2 (Fig. 1).

\section{Setting}

Mountjoy Prison is a large urban prison which at capacity houses 538 sentenced male prisoners. The mean age of prisoners incarcerated at this location is 34 years, with a third serving sentences of less than 12 months and almost half on restricted regimes (protection prisoners) [4].

\section{Data collection}

Data on study variables were collected from two sources; prisoners' electronic medical records and a researcheradministered questionnaire. All prisoners routinely complete a nurse committal interview on the day of incarceration which is recorded in the prisoners' medical records in the
Prisoner Healthcare Management System (PHMS). From the medical records review, we collected the following variables: age, country of origin, incarceration history, pre-incarceration accommodation, drug and alcohol use and treatment, previous HCV-related risk behaviour (history of IDU, history of sharing syringes and drug-taking paraphernalia (non-injection drug use equipment such as pipes, spoons, etc.) history of tattooing and the sharing of toothbrushes and razors while incarcerated).

The risk questionnaire was developed and piloted by the research team in conjunction with national experts in the area of $\mathrm{HCV}$ infection and prisoner groups. The questionnaire covered the 18 month time period since the previous study and included questions on: incarceration history, history of current $\mathrm{HCV}$-related risk behaviour both in the community and in prison (IDU, sharing syringes and other drug taking paraphernalia, receiving an unsterile tattoo) and engagement with harm reduction services (MAT and NSPs).

Questionnaires were completed prior to screening, but priority was given to completing screening over questionnaires, particularly in areas of the prison that housed enhanced-security prisoners. All study participants were given a patient information sheet and asked to sign a consent form. No inducements were offered.

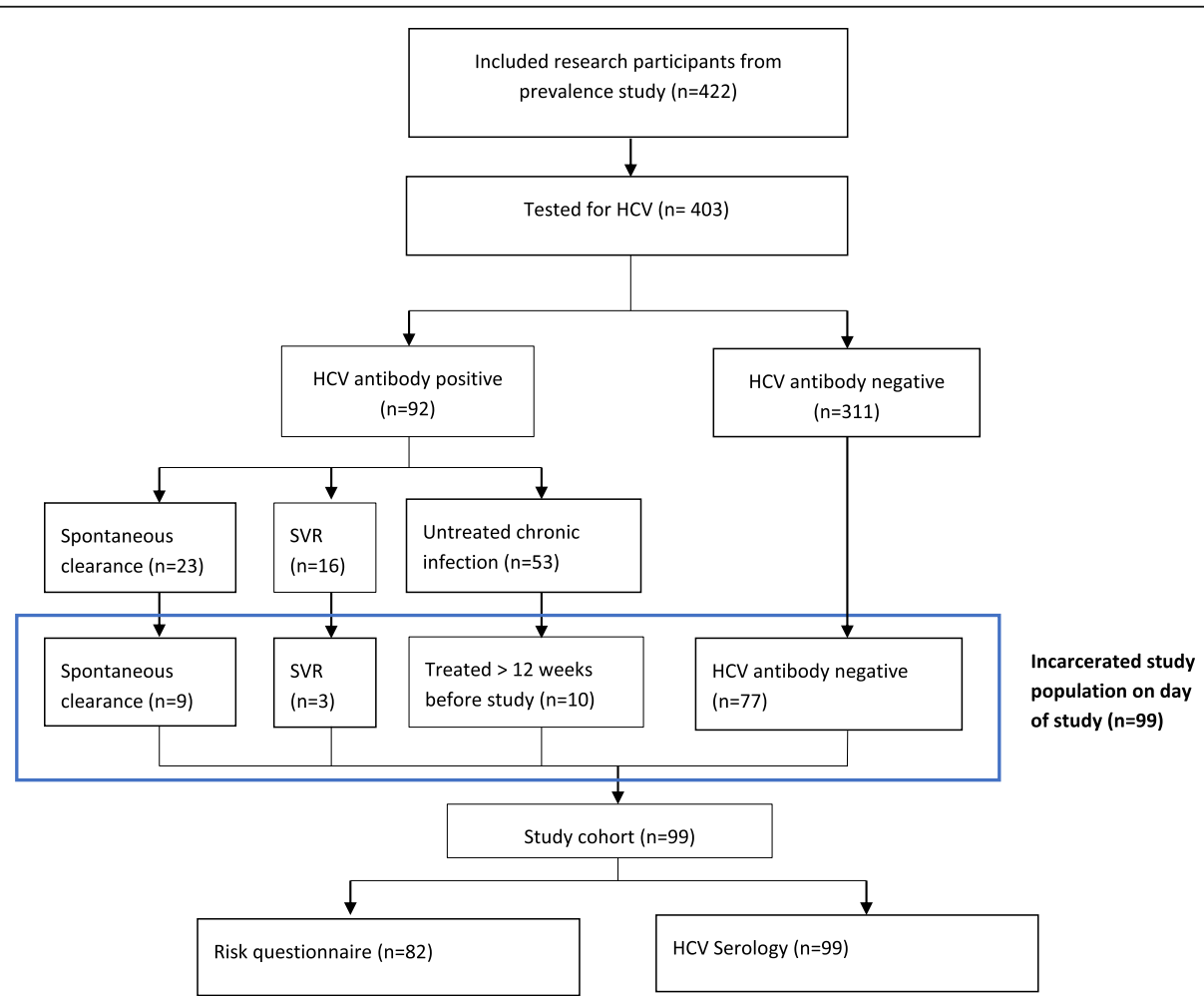

Fig. 1 Incarcerated study population on day of study with serological evaluation at 18 months. HCV: Hepatitis C virus; SVR: Sustained virologic response 


\section{Serological testing}

All participants were offered repeat serological screening for HIV, HBV, HCV antibody and reflex HCV RNA testing. First-line serological screening for hepatitis $B$ virus (HBV), HCV and human immunodeficiency virus (HIV) was carried out using chemiluminescent microparticle immunoassays on the Architect i4000sr automated platform (Abbott, Chicago, United States). Confirmatory testing of reactive samples was carried out using alternative assays. HIV serological diagnosis was based on the Architect HIV Ag/Ab Combo (Abbott, Chicago, United States) and confirmatory testing for reactive samples using the VIDAS HIV DUO Ultra (BioMérieux, Marcyl'Étoile, France) and HIV INNO-LIA HIV I/II Score (Innogenetics, Ghent, Belgium) assays. The Abbott Architect assays were used for $\mathrm{HBV}$-associated markers and to characterise the HBV infection status. Serological screening for $\mathrm{HCV}$ included the anti-HCV test (Abbott Architect), a third-generation immunoassay and the Abbott Architect HCV Ag assay. All anti-HCV reactive samples negative for $\mathrm{HCV}$ antigen were further investigated to confirm the presence of anti-HCV antibodies using the anti-HCV VIDAS (BioMérieux) and INNOLIA HCV Score (Innogenetics) assays. When HCV was confirmed serologically, molecular detection of $\mathrm{HCV}$ RNA was performed using the Abbott RealTime HCV assay. $\mathrm{HCV}$ genotyping was conducted on samples with detectable HCV RNA using the Abbott RealTime HCV Genotype II assay.

\section{Data analysis}

All data were anonymised and coded, double-entered and checked. Statistical analysis was performed using the Statistical Package for Social Sciences (version 23.0; SPSS UK Ltd.; Chersey, United Kingdom). Data were assessed for normality and where necessary, data were log-transformed for normalisation purposes. Data in tables are primarily expressed as means with standard deviation (SD) or numbers with percentages.

\section{Results}

\section{Demographic data}

A total of 99 prisoners with a mean age of 32.2 years (yrs.) consented to participate in the study. 94\% reported Ireland as their country of origin and $21 \%$ were homeless prior to incarceration. This cohort were first incarcerated in their late teens (mean age $=18.4 \mathrm{yrs}$.), had experienced multiple incarcerations $($ mean $=6.4)$ and had spent the majority of their young adult lives in prison (mean $=9.9$ yrs.). Just over half $(51 \%)$ of participants had a history of drug use, $43.9 \%$ a history of heroin use and 39\% a history of IDU. The mean age of first drug use was 14.8 yrs., first heroin use was 18.8 yrs., and first IDU was 20.6 yrs.
In terms of historical risk factors for $\mathrm{HCV}$ acquisition, 42.7\% gave a history of sharing drug taking equipment (paraphernalia), $17.3 \%$ of sharing syringes in the community, $22.5 \%$ of having had a prison tattoo and $23.8 \%$ a non-sterile community tattoo. Small numbers reported sharing a razor or toothbrush in a prison setting (2.5 and $1.3 \%$ respectively). A total of $42.1 \%$ reported having a history of methadone treatment, and the mean length of time on treatment was 6.3 years (Table 1).

\section{Recent risk for HCV infection}

Just under a quarter $(23.5 \%: n=99))$ of the original study cohort were available to follow up (Fig. 1). Of these 82 completed the updated risk questionnaire on current risk factors for HCV acquisition (Table 2). 69 of this group (85.2\%) remained incarcerated for the entire 18 month period since the previous study. The remainder $(n=13)$ had been released and re-incarcerated. Small numbers of patients engaged in recent IDU while incarcerated $(n=2)$ and on release into the community $(n=$ $3)$. Only one patient reported sharing syringes in the community post incarceration. Sharing drug taking paraphernalia both in the community $(n=2)$ and in the prison $(n=4)$ was a little more common than needle sharing. $20 \%(n=16)$ of participants were on MMT at the time of the study (Table 2).

\section{Blood-borne virus serology}

All 99 participants had repeat serology. The prevalence of HIV and HBV infection was 3\% and HCV antibody infection was $22.2 \%$. No new infections were identified either in those who had never been infected $(n=77)$, had self-cleared $(n=9)$ or achieved SVR $(n=12)$. There was one treatment failure (previously identified) (Table 3).

\section{Discussion}

Similar to other studies, this study found that drug users and PWID are over-represented in prisons [2, 3].. Over half of study participants had a history of drug use from an early age ( 14.5 yrs.). Heroin use and IDU were also common. Repeated incarcerations from a young age characterised this group. These findings reflect the recidivist nature of drug using prisoners and the limits of criminalisation and imprisonment in managing the health and social consequences of drug use and addiction. Of interest is the large turnover of prisoners in the 18 month period between the studies. Only $25 \%$ of the original cohort were available to retest. This reflects the dynamic nature of prison populations. Most prisoners serve short sentences ( $<12$ months) and are often transferred between prison locations during their prison sentence [20].

This study found no new HCV infections in a cohort of 99 prisoners who were followed up 18 months after 
Table 1 Patient demographics (medical records) on day of incarceration

\begin{tabular}{|c|c|c|c|c|}
\hline \multirow[t]{2}{*}{ Variable } & \multicolumn{4}{|c|}{ Participants } \\
\hline & Total & $\mathbf{n}$ & $\%$ & Mean (SD) \\
\hline Age (years) & 99 & & & $33.2(9.1)$ \\
\hline $18-24$ & & 13 & 13.1 & \\
\hline $25-34$ & & 46 & 46.5 & \\
\hline$\geq 35$ & & 40 & 40.4 & \\
\hline Age at first incarceration (years) & 81 & & & 18.4(5.9) \\
\hline Episodes of incarceration & 80 & & & $6.4(7.6)$ \\
\hline Total time incarcerated (years) & 75 & & & $9.9(6.8)$ \\
\hline Age at first drug use (years) & 66 & & & $14.8(2.9)$ \\
\hline Age at first heroin use (years) & 41 & & & $18.8(4.9)$ \\
\hline Age at first injecting drug use (years) & 66 & & & $20.6(5.7)$ \\
\hline Previous drug use (yes) & 98 & 50 & 51 & \\
\hline Visible injection site (yes) & 98 & 3 & 3.1 & \\
\hline Shared needles (yes) & 98 & 5 & 5.1 & \\
\hline Place of origin & 99 & & & \\
\hline Ireland & & 93 & 94 & \\
\hline Western Europe & & 1 & 1 & \\
\hline Eastern Europe & & 4 & 4 & \\
\hline Africa & & 1 & 1 & \\
\hline Accommodation before incarceration & 71 & & & \\
\hline Secure & & 56 & 78.9 & \\
\hline Homeless & & 15 & 21.1 & \\
\hline \multicolumn{5}{|l|}{ Risk factors for HCV acquisition } \\
\hline History of heroin use & 82 & 36 & 43.9 & \\
\hline History of injecting drug use & 82 & 32 & 39 & \\
\hline Shared needles in the community & 75 & 13 & 17.3 & \\
\hline Shared drug-taking equipment in the community & 75 & 32 & 42.7 & \\
\hline Shared razor in prison & 80 & 2 & 2.5 & \\
\hline Shared toothbrush in prison & 80 & 1 & 1.3 & \\
\hline Prison tattoo & 80 & 18 & 22.5 & \\
\hline Unsterile community tattoo & 80 & 19 & 23.8 & \\
\hline \multicolumn{5}{|l|}{ Alcohol use } \\
\hline Alcohol problem before incarceration & 81 & 12 & 14.8 & \\
\hline Treatment for alcohol use & 55 & 3 & 5.5 & \\
\hline \multicolumn{5}{|l|}{ Methadone maintenance treatment } \\
\hline History of methadone treatment & 76 & 32 & 42.1 & \\
\hline Length of time on methadone maintenance treatment & 20 & & & $6.3(5.6)$ \\
\hline
\end{tabular}

HCV Hepatitis c virus

having tested negative for HCV or having achieved SVR. This finding is welcome given the previously identified HCV-related risks linked with incarceration both nationally and internationally $[3,11,13,14,21]$. These risks include IDU, sharing syringes and other drug taking paraphernalia, having a non-sterile tattoo and factors independent of these but linked to incarceration such as sharing razors and tooth brushes and exposure to violent assaults [21, 22] Previous prison-based HCV incident studies have shown an in-prison incidence rate of $0.7-$ 1.0 per 100-py in the overall prison population and 18 24/100py among prisoners with a history of injecting drug use [23, 24]. A 2013 systematic review and metaanalysis found a $\mathrm{HCV}$ incidence among general 
Table 2 Results of updated risk questionnaire

\begin{tabular}{ll}
\hline Yes to variables & $\begin{array}{l}\text { Risk Question } \\
\text { Yes n (\%) }\end{array}$ \\
\hline Incarcerated since previous HCV test $(n=82)$ & $69(85.2)$ \\
Moved prison location $(n=82)$ & $18(22.0)$ \\
Engaged in IDU in prison $(n=82)$ & $2(2.4)$ \\
$\begin{array}{l}\text { Engaged in community IDU while on } \\
\text { release }(n=13)\end{array}$ & $3(23.1)$ \\
$\begin{array}{l}\text { Sharing needles in Prison }(n=82) \\
\text { Sharing needles in the community while } \\
\text { on release }(n=13)\end{array}$ & 0 \\
$\begin{array}{l}\text { Sharing drug paraphernalia in prison ( } n=82) \\
\text { Sharing drug paraphernalia in the community } \\
\text { while on release }(n=13)\end{array}$ & $1(7.1)$ \\
$\begin{array}{l}\text { Unsterile tattoo in Prison ( } n=82) \\
\text { Unsterile tattoo in the community while } \\
\text { on release }(n=13) \\
\text { Methadone }(n=82)\end{array}$ & $2(4.9)$ \\
\hline
\end{tabular}

HCV Hepatitis C Virus, IDU Injecting drug use

detainees of 1.4 per 100 -py and 16.4 per 100 -py in detainees with a history of IDU [3]. Studies reporting on $\mathrm{HCV}$ incidence in prisoners generally reported on larger numbers of prisoners and for longer follow up times than this study which may account for the higher incidence rates. However some studies have reported that prison is a protective factor for HCV infection due to reduced levels of IDU and access to MAT $[25,26]$. This may also be the case in Irish prisons where MAT is easily accessible to all those needing treatment. This includes continuing prisoners on MAT while incarcerated and linking them to community MAT services on release [5, 27].

The low numbers of patients engaging in riskbehaviour reported in this study is encouraging, in particular in those who had achieved SVR. The risk of HCV re-infection among PWID following achieving an SVR is considered relatively low ( $1-5 \%$ per year), but there is

Table 3 Serology results

\begin{tabular}{ll}
\hline Serology $(\boldsymbol{n}=\underline{99)}$ & Number $\boldsymbol{n}(\%)$ \\
\hline \hline HIV antibody positive & $3(3.0 \%)$ \\
HBV antibody positive & $3(3.0 \%)$ \\
HCV antibody positive & $22(22.2 \%)$ \\
HCV antibody negative & $77(77.8 \%)$ \\
HCV RNA negative/self-clearance & $9(9.0 \%)$ \\
HCV RNA negative (SVR) & $12(12.1 \%)$ \\
HCV RNA positive & $1(1.0 \%)$ (treatment failure) \\
\hline
\end{tabular}

HIV Human immunodeficiency Virus, $H B V$, Hepatitis B Virus, $H C V$ Hepatitis $C$ Virus, RNA Ribonucleic Acid, SVR sustained viral response considerable uncertainty around this estimate among those who continue to inject [28]. A number of studies have reported higher re-infection rates among current PWID and identified older age and IDU, at or posttreatment, as risk factors for re-infection [29]. The rate of HCV re-infection after successful treatment in prisoners is high, particularly among those who continue to inject drugs [30, 31]. Studies have reported an overall reinfection rate of 5.27 cases per 100-py. Re-infection was significantly higher among active drug users, HIV coinfected and those engaging in more than one risk behaviour after treatment [30, 31].

A small number $(n=13)$ of this study cohort had experienced prison release and re-incarceration between studies. Small numbers reported risk-behaviour which is encouraging. This finding may reflect the age of the cohort (mean age $=32.5 \mathrm{yrs}$.) and their existing knowledge of their HCV status. However the small numbers did not allow for comparison between those who remained incarcerated and those who had experienced release and re-incarceration. It also did not allow for comparisons between those never infected and those who had selfcleared or achieved SVR (previously infected). As already described most prisoners serve short sentences and many experience multiple cycles of release and reincarceration. Community release can be particularly problematic and is associated with elevated risk of death and overdose [32-34]. People just released from prison have multiple issues to contend with and linking to healthcare is often not a priority. Prison release is also a stressful time which can trigger relapse and a return to high-risk behaviour [32, 35, 36]. Coordinating HCV treatment in these circumstances can also prove challenging. Supporting prisoners and creating robust links to MAT and other healthcare services immediately on prison release should be a key public health priority and an area for further research [27,34].

The findings of this study support the ongoing need to develop and expand harm reduction services both in community and prison settings. Evidence shows that traditional harm reduction measures such as MAT and NSPs are effective in reducing self-reported syringe sharing [37]. Both interventions can reduce transmission of HIV and HCV, particularly when provided together. NSPs and MAT have been increasingly established but coverage remains poor and data on the quality of many of these services is unknown $[38,39]$. These initiatives are fragile, politically unpopular, under-resourced and increasingly undermined by a 'recovery agenda' that prioritises abstinence. Although access to HCV screening and treatment for PWID seems to be poorer in prison than in the community, access to harm reduction measures is even more limited [39, 40]. Approximately 60 out of more than 10,000 prisons worldwide provide 
NSPs [39]. HCV prevention is almost exclusively limited to verbal advice, leaflets and other measures directed to cognitive behavioural change [40]. While the extent of multiple risk behaviours for $\mathrm{HCV}$ in prisons is challenging, the setting does offer an ideal opportunity to provide a range of evidence-based interventions that can reduce $\mathrm{HCV}$ infection [39]. These include MAT, NSPs and condom availability. These have the added advantage of reducing HIV transmission and, in the case of MAT, fatal overdose in the immediate post-release period. Despite the evidence-base for the effectiveness of these interventions in the reduction of the transmission of BBVs, there is poor coverage of these in prisons globally [41].

Incident studies in prison populations are rarely conducted. They are often difficult to design and implement. In this context the findings from this study are important since they add to what is a very small pool of data on incident $\mathrm{HCV}$ infection in prisoners. The findings are limited by the small numbers $(n=99)$ who were available for follow up and who completed the questionnaire $(n=$ 82 ). The small numbers prevented any meaningful statistical comparison between those who remained incarcerated and those who had experienced released and reincarcertaion and between those never infected and previously infected. A strength of the study is the use of serum samples rather than historical blood-borne virus screening data from chart records. The use of current serology is unusual in these types of studies and with high levels of both sensitivity and specificity for this method offers increased validity to this study over those using saliva samples. A further strength is that all eligible participants agreed to follow up serology.

The use of a research-completed questionnaire has both strengths and limitations. The researchers completing the questionnaire were unknown to the prisoners which may have allowed for more frank disclosure of risk behaviour. The design of our study allowed researchers to spend time with the prisoner and to add clarification regarding the meaning/interpretation of the questions. While overcoming the issue of literacy, it was time-consuming which impacted on completion rates. There are a number of further limitations to this study. It was single-site and only included male prisoners, making the findings more difficult to generalise both nationally and internationally. Data collected on the sharing of syringes and drug-taking paraphernalia did not distinguish between reception and distribution and did not report on the frequency of sharing. In addition, owing to the nature of the study we did have a small ' $n$ ' for a number of variables of interest, caution must be used in the interpretation of the results until they are replicated in larger studies. There were limits on allocated time to access prisoners, consequently, screening was prioritised over the completion of the risk questionnaire. This was particularly an issue with protection prisoners where enhanced security measures were in place.

\section{Conclusions}

This study reported no new HCV infections over an 18 month period in a cohort of prisoners $(n=99)$ known to be not infected or successfully treated for HCV. Small numbers engaged in $\mathrm{HCV}$-related risk behaviour while incarcerated and on release. A larger multi-site study is required to fully understand the rates and associated risks of $\mathrm{HCV}$ infection in Irish prisoners, but this preliminary study suggests that existing measures including MAT availability are protective in preventing $\mathrm{HCV}$ infection in this group.

\section{Abbreviations}

HCV: Hepatitis C virus; IDU: Injecting drug use; HIV: Human Immunodeficiency Virus; MAT: Medication assisted treatment; PWID: People who injects drugs; PY: Person-year; IPS: Irish Prison Service; NSPs: Needle syringe programmes; DAAs: Direct-acting antivirals; HBV: Hepatitis B virus; SVR: Sustained virologic response; PHMS: Prisoner Healthcare Management System; RNA: Ribonucleic acid; Yrs.: Years; SD: Standard deviation

\section{Acknowledgements}

The authors would like to acknowledge the support of the Hepcare Europe team at the Mater Misericordiae Hospital and University College Dublin, and the staff and the management of the Irish Prison Service. The authors would also like to thank the prisoners who participated in the study.

\section{Authors' contributions}

Conceived and designed and designed the idea: DC, GA, WC, CF, AH, MK, SMCK, SJM, EOC, DOR, JSL. Had full access to all the data in the study and taking responsibility for the integrity of the data and the accuracy of the data analysis: DC, EL, TMCH, RM. Contributed to the writing of the manuscript: DC, GA, EL, RM, MOM, DOR. Contributed to the statistical analysis: DC, EL, RM. Critical revision of the manuscript: DC, GA, WC, CF, AH, MK, EL, TMCH, SMCK, SJM, RM, EOC, MOM, DOR, JSL. All authors read and approved the final manuscript.

\section{Funding}

This study was partly funded by a collaboration agreement with AbbVie. Author MO'M is an employee of Abbvie and worked in collaboration with the research team on the protocol design.

\section{Availability of data and materials}

The datasets used and/or analysed during the current study are available from the corresponding author on reasonable request.

\section{Declarations}

Ethics approval and consent to participate

Ethical approval for the research was granted by The Mater Misericordiae University Hospital Research Ethics Committee (Ref:1/378/1839) and the Irish Prison Service (IPS) Ethics Review Committee.

Consent for publication

Not applicable.

Competing interests

The authors declare that they have no competing interests.

Author details

${ }^{1}$ School of Medicine, University College Dublin, Dublin, Ireland. ${ }^{2}$ Irish Prison Service, Dublin, Ireland. ${ }^{3}$ Trinity College Dublin, Dublin, Ireland. ${ }^{4}$ Department of Infectious Diseases, Mater Misericordiae University Hospital, Dublin, Ireland. 
${ }^{5}$ St. James' Hospital, Dublin, Ireland. ${ }^{6}$ Mater Misericordiae University Hospital, Dublin, Ireland. ${ }^{7}$ Abbvie Ltd, Dublin, Ireland.

\section{Received: 27 February 2021 Accepted: 30 May 2021} Published online: 08 June 2021

\section{References}

1. Stanaway JD, Flaxman AD, Naghavi M, Fitzmaurice C, Vos T, Abubakar I, et al. The global burden of viral hepatitis from 1990 to 2013: findings from the global burden of disease study 2013. Lancet. 2016;388:1081-8. https:// doi.org/10.1016/S0140-6736(16)30579-7.

2. Degenhardt L, Peacock A, Colledge S, Leung J, Grebely J, Vickerman P, et al. Global prevalence of injecting drug use and sociodemographic characteristics and prevalence of HIV, HBV, and HCV in people who inject drugs: a multistage systematic review. Lancet Glob Health. 2017:5:e1192207. https://doi.org/10.1016/S2214-109X(17)30375-3.

3. Larney S, Kopinski H, Beckwith CG, Zaller ND, Jarlais DD, Hagan $H$, et al. Incidence and prevalence of hepatitis $\mathrm{C}$ in prisons and other closed settings: Results of a systematic review and meta-analysis. Hepatology. 2013; 58:1215-24. https://doi.org/10.1002/hep.26387.

4. Irish Prison Service. Irish Prison Service Annual Report 2017: Dublin; 2017. https://www.irishprisons.ie/wp-content/uploads/documents_pdf/IPS-annua Ireport-2017.pdf

5. Delargy I, Crowley D, Van Hout MC. Twenty years of the methadone treatment protocol in Ireland: reflections on the role of general practice. Harm Reduct J. 2019;16:5. https://doi.org/10.1186/s12954-018-0272-4.

6. Drummond A, Codd M, Donnelly N, McCausland D, Mehegan J, Daly L, et al. Study on the prevalence of drug use, including intravenous drug use, and blood-borne viruses among the Irish prisoner population. Dublin: National Advisory Committee on Drugs and Alcohol; 2014. https://www.drugsanda Icohol.ie/21750/1/Full-Drug-use-among-Irish-prisoner-population.pdf

7. Allwright S. Prevalence of antibodies to hepatitis B, hepatitis C, and HIV and risk factors in Irish prisoners: results of a national cross sectional survey. BMJ. 2000;321:78-82. https://doi.org/10.1136/bmj.321.7253.78.

8. Crowley D, Murtagh $R$, Cullen W, Lambert JS, McHugh T, Van Hout MC Hepatitis $C$ virus infection in Irish drug users and prisoners - a scoping review. BMC Infect Dis. 2019;19:702. https://doi.org/10.1186/s12879-019-4218-6.

9. Department of Health. Hepatitis C Screening (NCEC National Clinical Guideline No. 15). Dublin; 2017. https://health.gov.ie/wp-content/uploads/2 017/08/Hepatitis-C-NCG-15_v8.pdf

10. Crowley D, Murtagh R, Cullen W, Keevans M, Laird E, McHugh T, et al. Evaluating peer-supported screening as a hepatitis C case-finding model in prisoners. Harm Reduct J. 2019;16:42. https://doi.org/10.1186/s12954-0190313-7.

11. Crowley D, Lambert JS, Betts-Symonds G, Cullen W, Keevans M, Kelly E, et al. The seroprevalence of untreated chronic hepatitis $\mathrm{C}$ virus $(\mathrm{HCV})$ infection and associated risk factors in male Irish prisoners: a cross-sectional study, 2017. Eurosurveillance. 2019;24:1800369. https://doi.org/10.2807/1560-7917. ES.2019.24.14.1800369

12. Larney SG, Beckwith CD, Zaller NT, Montague B, Rich J. "Seek, test, treat and retain" for hepatitis $C$ in the United States criminal justice system. Int J Prison Health. 2014;10:164-71. https://doi.org/10.1108/IJPH-11-2013-0051.

13. Bretaña NA, Boelen $L$, Bull $R$, Teutsch $S$, White PA, Lloyd AR, et al. Transmission of hepatitis C virus among prisoners, Australia, 2005-2012. Emerg Infect Dis. 2015;21:765-74. https://doi.org/10.3201/eid2105.141832.

14. Post JJ, Lloyd AR, Dolan KA, Whybin LR, Carter IWJ, Haber PS. Acute hepatitis $C$ virus infection in an Australian prison inmate: tattooing as a possible transmission route. Med J Aust. 2001;174:183-4. https://doi.org/10. 5694/j.1326-5377.2001.tb143214.x

15. Rumble C, Pevalin DJ, O'Moore É. Routine testing for blood-borne viruses in prisons: a systematic review. Eur J Pub Health. 2015;25:1078-88. https://doi. org/10.1093/eurpub/ckv133.

16. Arain A, Robaeys G, Stöver H. Hepatitis C in European prisons: a call for an evidence-informed response. BMC Infect Dis. 2014;14(Suppl 6):S17. https:// doi.org/10.1186/1471-2334-14-S6-S17.

17. Crowley D, Van Hout MC, Lambert JS, Kelly E, Murphy C, Cullen W. Barriers and facilitators to hepatitis C (HCV) screening and treatment-a description of prisoners' perspective. Harm Reduct J. 2018;15:62. https://doi.org/10.1186/ s12954-018-0269-z.

18. Crowley D, Van Hout MC, Murphy C, Kelly E, Lambert JS, Cullen W. Hepatitis $C$ virus screening and treatment in Irish prisons from a governor and prison officer perspective - a qualitative exploration. Heal Justice. 2018;6:23. https:// doi.org/10.1186/s40352-018-0081-6.

19. Barror S, Avramovic G, Oprea C, Surey J, Story A, Macías J, et al. HepCare Europe: a service innovation project. HepCheck: enhancing HCV identification and linkage to care for vulnerable populations through intensified outreach screening. A prospective multisite feasibility study. J Antimicrob Chemother. 2019;74(Supplement_5):v39-46. https://doi.org/10.1 093/jac/dkz455.

20. Martin NK, Vickerman P, Dore GJ, Hickman M. The hepatitis C virus epidemics in key populations (including people who inject drugs, prisoners and MSM). Curr Opin HIV AIDS. 2015;10:374-80. https://doi.org/10.1097/ $\mathrm{COH} .0000000000000179$.

21. Altice FL, Azbel L, Stone J, Brooks-Pollock E, Smyrnov P, Dvoriak S, et al. The perfect storm: incarceration and the high-risk environment perpetuating transmission of HIV, hepatitis C virus, and tuberculosis in Eastern Europe and Central Asia. Lancet. 2016;388:1228-48. https://doi.org/10.1016/S01406736(16)30856-X.

22. Post JJ, Arain A, Lloyd AR. Enhancing Assessment and Treatment of Hepatitis C in the Custodial Setting. Clin Infect Dis. 2013:57(suppl_2):S70-4. https://doi.org/10.1093/cid/cit265.

23. Søholm J, Holm DK, Mössner B, Madsen LW, Hansen JF, Weis N, et al. Incidence, prevalence and risk factors for hepatitis C in Danish prisons. PLoS One. 2019;14:e0220297. https://doi.org/10.1371/journal.pone.0220297.

24. Luciani F. Bretaña NA rvi., Teutsch S, Amin J, Topp L, Dore GJ, et al. a prospective study of hepatitis $C$ incidence in Australian prisoners. Addiction. 2014;109:1695-706. https://doi.org/10.1111/add.12643.

25. Taylor A, Munro A, Allen E, Dunleavy K, Cameron S, Miller L, et al. Low incidence of hepatitis C virus among prisoners in Scotland. Addiction. 2013; 108:1296-304. https://doi.org/10.1111/add.12107.

26. Marco A, Gallego C, Caylà JA. Incidence of hepatitis C infection among prisoners by routine laboratory values during a 20-year period. PLoS One. 2014;9:e90560. https://doi.org/10.1371/journal.pone.0090560.

27. Hedrich D, Alves P, Farrell M, Stöver H, Møller L, Mayet S. The effectiveness of opioid maintenance treatment in prison settings: a systematic review. Addiction. 2012;107:501-17. https://doi.org/10.1111/j.1360-0443.2011.03676.x.

28. Aspinall EJ, Mitchell W, Schofield J, Cairns A, Lamond S, Bramley P, et al. A matched comparison study of hepatitis $C$ treatment outcomes in the prison and community setting, and an analysis of the impact of prison release or transfer during therapy. J Viral Hepat. 2016;23:1009-16. https://doi.org/1 $0.1111 /$ jvh.12580.

29. Martinello M, Grebely J, Petoumenos K, Gane E, Hellard M, Shaw D, et al. $\mathrm{HCV}$ reinfection incidence among individuals treated for recent infection. J Viral Hepat. 2017:24:359-70. https://doi.org/10.1111/jvh.12666.

30. Liu S, Watcha D, Holodniy M, Goldhaber-Fiebert JD. Sofosbuvir-Based Treatment Regimens for Chronic, Genotype 1 Hepatitis C Virus Infection in U.S. Incarcerated Populations. Ann Intern Med. 2014;161:546. https://doi. org/10.7326/M14-0602.

31. Marco A, Esteban JI, Solé C, da Silva A, Ortiz J, Roget M, et al. Hepatitis C virus reinfection among prisoners with sustained virological response after treatment for chronic hepatitis C. J Hepatol. 2013;59:45-51. https://doi.org/1 0.1016/j.jhep.2013.03.008.

32. Merrall ELC, Kariminia A, Binswanger IA, Hobbs MS, Farrell M, Marsden J, et al. Meta-analysis of drug-related deaths soon after release from prison. Addiction. 2010;105:1545-54. https://doi.org/10.1111/j.1360-0443.2010.02990.x.

33. Binswanger IA. Mortality after prison release: opioid overdose and other causes of death, risk factors, and time trends from 1999 to 2009. Ann Intern Med. 2013;159:592. https://doi.org/10.7326/0003-4819-159-9-20131105000005.

34. Stone J, Martin NK, Hickman M, Hutchinson SJ, Aspinall E, Taylor A, et al. Modelling the impact of incarceration and prison-based hepatitis $C$ virus ( $\mathrm{HCV}$ treatment on HCV transmission among people who inject drugs in Scotland. Addiction. 2017;112:1302-14. https://doi.org/10.1111/add.13783.

35. Degenhardt L, Larney S, Kimber J, Gisev N, Farrell M, Dobbins T, et al. The impact of opioid substitution therapy on mortality post-release from prison: retrospective data linkage study. Addiction. 2014;109:1306-17. https://doi. org/10.1111/add.12536.

36. Kariminia A, Law MG, Butler TG, Corben SP, Levy MH, Kaldor JM, et al. Factors associated with mortality in a cohort of Australian prisoners. Eur J Epidemiol. 2007;22:417-28. https://doi.org/10.1007/s10654-007-9134-1.

37. Aspinall EJ, Corson S, Doyle JS, Grebely J, Hutchinson SJ, Dore GJ, et al. Treatment of Hepatitis C Virus Infection Among People Who Are Actively 
Injecting Drugs: A Systematic Review and Meta-analysis. Clin Infect Dis. 2013;57(suppl_2):S80-9. https://doi.org/10.1093/cid/cit306.

38. EMCDDA. Hepatitis $C$ among drug users in Europe: epidemiology, treatment and prevention. Lisbon: Publications Office; 2016. https://www.emcdda. europa.eu/system/files/publications/2953/TDXD16002ENN_final_web.pdf

39. Larney S, Peacock A, Leung J, Colledge S, Hickman M, Vickerman P, et al.

Global, regional, and country-level coverage of interventions to prevent and manage HIV and hepatitis C among people who inject drugs: a systematic review. Lancet Glob Health. 2017;5:e1208-20. https://doi.org/10.1016/ S2214-109X(17)30373-X.

40. Bielen R, Stumo SR, Halford R, Werling K, Reic T, Stöver H, et al. Harm reduction and viral hepatitis $C$ in European prisons: a cross-sectional survey of 25 countries. Harm Reduct J. 2018;15:25. https://doi.org/10.1186/s12954018-0230-1.

41. Wiessing L, Ferri M, Běláčková V, Carrieri P, Friedman SR, Folch C, et al. Monitoring quality and coverage of harm reduction services for people who use drugs: a consensus study. Harm Reduct J. 2017;14:19. https://doi. org/10.1186/s12954-017-0141-6.

\section{Publisher's Note}

Springer Nature remains neutral with regard to jurisdictional claims in published maps and institutional affiliations.

Ready to submit your research? Choose BMC and benefit from:

- fast, convenient online submission

- thorough peer review by experienced researchers in your field

- rapid publication on acceptance

- support for research data, including large and complex data types

- gold Open Access which fosters wider collaboration and increased citations

- maximum visibility for your research: over $100 \mathrm{M}$ website views per year

At BMC, research is always in progress.

Learn more biomedcentral.com/submissions 